\title{
Asteroids (Echinodermata) from the Crackers Member (lower Aptian, Deshayesites forbesi Zone) on the Isle of Wight (UK), with a revision of fossil Pseudarchasteridae
}

Andy Gale

School of Earth and Environmental Sciences, University of Portsmouth, Burnaby Building, Burnaby Eoad, Portsmouth P013QL, UK; E-mail address: andy.gale@port.ac.uk

A B S T R A C T. Asteroids from the lower Aptian Lower Greensand of the Isle of Wight are described. Two articulated specimens are referred to the extant paxillosid family Pseudarchasteridae and transferred to a living genus, i.e., Paragonaster, P. wightensis (Breton, 1992). Isolated marginal plates are assigned to the widespread Cretaceous astropectinid genus Coulonia, and described as $C$. caseyi sp. nov. The Cretaceous genus Comptonia Gray, 1840 is referred to the Pseudarchasteridae and revised taxonomically, with the recognition of two species; C. elegans Gray, 1840 and C. bretoni sp. nov. Paragonaster wightensis is the oldest known member of the Pseudarchasteridae.

Keywords:

Lower Cretaceous

Paxillosida

England

New species

\section{Introduction}

Articulated asteroids are amongst the rarest of fossils, because the calcitic plates or ossicles disperse rapidly after death of the animal. The main mode of preservation of articulated specimens is by rapid burial under sediment (obrution) which is not subsequently disturbed by bioturbation (Goldring and Stephenson, 1972). However, dissociated asteroid ossicles are fairly common fossils, having formed the basis of numerous studies, particularly of Jurassic 
and Cretaceous material (e.g., Spencer, 1913; Müller, 1953; Gale, 1987, 1988; Jagt, 2000). The marginal ossicles of the families Astropectinidae and Goniasteridae, in particular, are sometimes large and conspicuous and are found commonly by collectors. Other, usually smaller, ossicles of the abactinal and actinal surfaces, the mouth frame and the ambulacral groove, also provide important taxonomic information (Gale, 2011a, b, 2018).

The Lower Greensand Group of southern England has provided negligible records of asteroids, which is unusual for a fossiliferous, marine Cretaceous deposit. However, it turns out that two illustrated specimens from old collections actually originated from the Lower Greensand, but were incorrectly labelled as having come from the Upper Greensand. The specimen of Astropecten ? n. sp. described and figured by Spencer (1905, p. 90, pl. 25, fig. 2), stated to be from the "Upper Greensand, ?Blackdown", is actually from the Folkestone Sand Formation (lower Albian) at Folkestone (Kent) or a nearby locality; the matrix is highly distinctive and the specimen is identified here as a specifically indeterminate form of Coulonia. Secondly, a specimen originally described as Nymphaster coombi (Spencer, 1905, pl. 19, fig. 3; type of Comptonia wightensis Breton, 1992), was stated to have originated from the Upper Greensand of the Isle of Wight. However, the fine, slightly micaceous, silty sand matrix contains gastropods that are unique to concretions in the Crackers Member (lower Aptian; see Fig. 1) in the upper Atherfield Clay of Chale Bay, Isle of Wight (Gale, in Andrew et al., 2016) from which the specimen certainly originated.

Collecting by the late brothers Claud W. and Edward V. Wright in the Crackers at Atherfield, shortly after the $2^{\text {nd }}$ World War, produced numerous small fossils, including marginals of an astropectinid asteroid here identified as Coulonia caseyi sp. nov. Lastly, Martin Simpson's recent collecting from the Crackers at Atherfield has yielded the arm tip of a second specimen of $P$. wightensis, which shows important details of the abactinal surface of that species.

The Lower Greensand species described herein on the basis of articulated material has traditionally been assigned to the valvatid family Goniasteridae, a family with an extensive Cretaceous record (e.g., Breton, 1979, 1992; Gale, 1987, 1988; Jagt, 2000). A more detailed study of the material indicates that it actually belongs to the Pseudarchasteridae (formerly Pseudarchasterinae), which are nowadays placed in the order Paxillosida (e.g., Mah and Foltz, 2011) and which are strongly convergent with the Goniasteridae. Lastly, fossil occurrences of supposed pseudarchasterids are reviewed. 


\section{Systematic palaeontology}

Abbreviations.

NHMUK Natural History Museum, London, UK

IoWM Isle of Wight Museum, UK

SM Sedgwick Museum, Cambridge, UK

Order Paxillosida Perrier, 1884

Family Astropectinidae Gray, 1840

Diagnosis. Five-armed, flattened paxillosids, which possess a broad marginal frame made up of paired, opposing supero- and inferomarginals; fascioles run abactinally-actinally between individual supero- and inferomarginal pairs in a majority of genera; abactinal surface composed of small paxillae; actinals, when present, in well-defined rows of imbricating plates.

Genus Coulonia de Loriol, 1873

Diagnosis. Astropectinids which possess broad interradii and relatively short arms; marginal frame broad, made up of short, broad inferomarginals which taper gently towards lateral margins and slightly narrower superomarginals; deep fascioles run abactinally-actinally between each supero-inferomarginal pair, extending over nearly half breadth of marginals.

Type species. Coulonia neocomiensis de Loriol, 1873, by monotypy.

Synonyms. Cuneaster Hess, 1955 and Betelgeusia Blake and Reid, 1998.

Coulonia caseyi sp. nov.

Fig. 5A-E

Diagnosis. Coulonia in which superomarginals are proportionately narrow and possess only a short lateral fasciolar surface. Inferomarginals with broad fasciolar surfaces, extending across $40 \%$ of the breadth of the ossicle, and irregular, coarse spine pits on the actinal surface. 
Material. Three inferomarginal and one superomarginal ossicle from the Crackers Member, Atherfield (Isle of Wight, UK); lower Aptian, Deshayesites forbesi Zone. NHMUK EE 1666216665.

Types. The well-preserved inferomarginal figured (Fig. 5A-C) is the holotype (NHMUK EE 16662); the other three ossicles are paratypes (NHMUK EE 16663-16665).

Derivation of name. In honour of the extensive research into the Lower Greensand carried out by the late Raymond Casey.

Description. The species is known only from isolated marginal ossicles. Interradial inferomarginals (Fig. 5A-C) are rectangular in actinal aspect, and twice as broad as long. The actinal surface is gently convex, and bears large spine bases set in irregular rows across the breadth of the ossicle. The articular surfaces for adjacent proximal and distal inferomarginals form rectangular ridges which extend over half of the total breadth of the plates. The lateral margins of the articular surfaces are vertical. Deep grooves for fascioles are present between the lateral portions of the inferomarginals, and these extend, as shallow grooves, to the actinal margins of the plates. The articulation surface for the superomarginals does not extend to the lateral margin of the inferomarginals. The inferomarginals from the base of the arm (Fig. 5E) have a similar sculpture, but the inner (actinal) margin of the plates is angled to the broader proximal and narrower distal margins, reflecting the taper of the arm. The superomarginal (Fig. 5B, D) is oval in proximal/distal aspect, and the external surface is moderately convex; the ossicle is significantly narrower than the corresponding inferomarginal. The articular facets between adjacent superomarginals are broad, and extend over most of the total breadth of the ossicle. The groove for an intermarginal fasciole is thus significantly shallower than on the inferomarginals. The external surface of the superomarginal is smooth, perhaps on account of abrasion.

Remarks. Coulonia caseyi sp. nov. differs from the type species, Coulonia neocomiensis (see Hess 1955, figs 16-22), from the lower Hauterivian of Switzerland, in the narrow superomarginals which possess a small intermarginal depression for a fasciole. It differs from C. platyspina Hess and Blake, 1995 from the Barremian of Morocco (Fig. 5G) and C. reidi (Fig. $5 \mathrm{H}, \mathrm{I})$ from the Cenomanian of Texas in the narrower inferomarginals, and the form of the 
superomarginals. In these two species, the abactinal surface of the superomarginals is nearly flat, and successive plates articulate by means of two specialized surfaces.

Family Pseudarchasteridae Sladen, 1889

Diagnosis. Paxillosid asteroids which possess a marginal frame carrying shallow intermarginal fascioles; tube feet with a flattened termination; oral ossicle pairs with a single, proximally directed spine in each interradius.

Remarks. There has been some disagreement as to the characters diagnostic of this group and its validity. For Spencer and Wright (1966), the presence of simple (i.e., non-alveolar) pedicellariae was notable; for Halpern (1972) the sole diagnostic character was the presence of unpaired median spines on the proximal margin of each pair of oral ossicles. Clarke and Downey (1992) did not even recognise the subfamily within the Goniasteridae. However, it is now evident that the pseudarchasterids are Paxillosida which have evolved convergently with the valvatid family Goniasteridae, in possession of a very robust marginal frame constructed of block-like plates. Their paxillosid affinities are displayed by the presence of shallow grooves, called fascioles, between successive marginal plates, and the total absence of the alveolar pedicellariae typical of valvatids (Gale, 2011a). Recent molecular studies have more recently identified their paxillosid affinity (Mah and Foltz, 2011) and the Pseudarchasteridae is therefore restored here to full family status.

There have been rather numerous claims for fossil occurrences of pseudarchasterids, which are reviewed in sequence of age below.

- Blake (1986) identified the Late Jurassic (Tithonian) species Pentasteria (P.) portlandicus Hess, 1955, from Dorset (UK), as a Pseudarchaster. This was discussed by Gale (2011a), who concluded, from a detailed analysis of the spines in particular, that this was originally referred correctly to the astropectinid Pentasteria (Pentasteria).

- Capellia mauricei Blake and Reid, 1998, from the upper Albian of Texas, was described as a goniasterid "close to Pseudarchaster" (Blake and Reid, 1998, p. 514). However, the presence of broad, deep fascioles between the inferomarginals and the typical paxillosid abactinal paxillae allow certain placement of this taxon within the Astropectinidae. 
- The reference to Formalhautia Blake and Reid, 1998 by Blake and Jagt (2005, p. 185) as a typical pseudarchasterine is evidently an error, as from the description they clearly refer to Capellia (see above).

- Sucia suavis Blake, 1973 from the Upper Cretaceous of Washington State, USA, is morphologically close to extant Paragonaster, in its possession of shallow intermarginal fascioles and the single row of abactinals extending along the radius between the superomarginals.

- Skiaster vikingr Blake and Jagt, 2005, from the lower Danian (Paleogene) of Denmark, possesses rather deep intermarginal fascioles and abactinal paxillae, but the superomarginals make contact over the radius. This condition is not seen in any extant pseudarchasterid.

- Pseudarchaster motutararensis Eagle, 1999 from the Lower Miocene of New Zealand, is an articulated asteroid which shows only the actinal surface, interpreted by Eagle as the abactinal surface. No details of the superomarginals marginals are visible, and the specimen can best be considered as a probable goniasterid.

Included genera. Paragonaster Sladen, 1889, Pseudarchaster Sladen, 1889, Perissogonaster Fisher, 1913, Gephyreaster Fisher, 1910, Comptonia Gray, 1840, Sucia Blake, 1973 and ?Skiaster Blake and Jagt, 2005.

Genus Paragonaster Sladen, 1889

Type species. P. ctenipes Sladen, 1889, by subsequent designation of Fisher (1919).

Diagnosis. Pseudarchasterids possessing narrow, elongated arms in which the superomarginals are separated by a single row of radial plates; arms well demarcated from disc; unpaired interradial marginals absent.

Paragonaster wightensis (Breton, 1992)

Fig. 2A-B, D

1905 Nymphaster Coombi Forbes; Spencer, p.15, pl. 19, fig. 3.

1907 Calliderma smithiae Forbes; Spencer, p. 123.

1992 Comptonia wightensis Breton, p. 316, fig. 129. 
Type. NHMUK E 48620, said to have come from the Upper Greensand of the Isle of Wight, but the presence of distinctive gastropod species in the matrix indicates its source as the Crackers Member of the Atherfield Clay (Gale, in Andrew et al., 2016).

Material. The holotype, plus an arm tip displaying the abactinal surface (IWCMS 2019.3) collected by Martin Simpson of Chale.

Description. The type specimen (Fig. 2B, D) preserves three arms and most of the disc, and displays the actinal surface. Some of the marginals are slightly displaced, as are all the actinals and adambulacrals, but the orals remain essentially in place. The arms are moderately elongated (R:r =3:1), taper evenly, and the interradii are evenly curved. The interradial inferomarginals are slightly broader than long, and the actinal/lateral surfaces evenly and gently curved. The inferomarginals narrow markedly into the base of the arms, and the distal inferomarginals are slightly longer than broad. There are approximately 14 marginal pairs on each side of the arm. The external surfaces of the inferomarginals bears shallow, inconspicuous spine pits. Displaced inferomarginals (Fig. 2D, arrowed) show the presence of a narrow, inset intermarginal groove, in which a shallow fasciole was present. Little detail of the orals, adambulacrals and actinals is clear. The actinals are thin, imbricating polygonal plates, and the adambulacrals block-like. The actinal surface of the orals is triangular and gently convex. The well-preserved arm tip (Fig. 2A) shows the abactinal surface, and the terminal ossicle is in place; six to seven superomarginals are preserved in place on each side of the arm. A scatter of marginals and ambulacrals is present distal to the articulated tip. The superomarginals are rectangular, and the external face is evenly and gently curved. The terminal is convex and kite-shaped, and two tiny, wedge-shaped superomarginals contact its distal lateral surfaces (pair 1). Proximal to these, a pair of larger, trapezoidal marginals contact the proximal part of the terminal (pair 2) and touch over the radius. Superomarginal pairs 2-4 articulate over the radius with a zig-zag contact. More proximal marginal pairs are separated by a single row of abactinal ossicles (radials), which are triangular, and about 25 per cent the breadth of the superomarginals. They bear fine granular spines.

Remarks. Paragonaster wightensis is closely similar to living species of in the presence of a single row of small, rectangular radials separating the superomarginals along much of the arm, and the broad, rounded interradii. It differs from P. stenostichus (Fig. 3) in the shorter 
arms, and shorter, broader radials between the superomarginals; in P. stenostichus approximately 1.5 radials per superoparginal, whereas in $P$. wightensis more than two are present. Paragonaster wightensis differs from the closely related genus Perissogonaster (Fig. 4) in lacking an interradial pair of marginals.

Comptonia Gray, 1840

Type species. Comptonia elegans Gray, 1840, by monotypy.

Diagnosis. Pseudarchasterids in which the interradii are strongly curved, and the interradial marginals are very narrow; the abactinal plates set between the superomarginals in the proximal arm are approximately as broad as the superomarginals.

Included species. Comptonia elegans and C. bretoni sp. nov.

Remarks. Comptonia is a distinctive form, which differs from all other pseudarchasterids in the acute interradii, the narrow interradial marginals and the broad radial plates in the proximal arm (Fig. 2C). Here I separate the material described and figured by Breton (1979, 1992) as a new species (see below).

Comptonia elegans Gray, 1840

Figs. 2C, 5F.

*1840 Comptonia elegans Gray, p. 278.

1848 Stellaster elegans Gray; Forbes, p. 476.

1850 Stellaster elegans Gray; Forbes, in Dixon, p. 336, pl. 22, fig. 9.

1905 Comptonia elegans Gray; Spencer, p. 71, pl. 17, fig. 4.

non 1992 Comptonia elegans Gray; Breton, p. 32, pl. 5, fig. 21.

non 1992 Comptonia elegans Gray; Breton, p. 309, pl. 38, figs 1-3.

Diagnosis. Comptonia in which the interradii are acutely angled, and the interradial superomarginals are very narrow and steep, entirely lacking an abactinal surface. 
Remarks. This species is known from two specimens from the Late Albian Upper Greensand of Blackdown, Devon, UK. It differs from C. bretoni sp. nov. in the more acutely angled interradii, the very narrow interradial superomarginals with steep lateral surfaces and the extension of adradials into the base of the arm.

Comptonia bretoni sp. nov.

1979 Comptonia elegans Gray; Breton, p. 32, pl. 5, fig. 21.

1992 Comptonia elegans Gray; Breton, p. 309, pl. 38, figs 1-3.

Types. The specimen figured by Breton (1992, pl. 38, figs 2-3) is the holotype. Collection Boutillier, Université de Caen. The other specimen figured by Breton (1979, pl. 5, fig. 21; 1992, pl. 38, fig. 1) is paratype. Upper Albian or lower Cenomanian of Le Havre (Normandy, France).

Diagnosis. Comptonia in which the interradii are rounded, and the arms poorly demarcated from the disc. The interradial superomarginals are slightly narrower than those of the proximal arm.

Derivation of name. In honour of the research of Gérard Breton (Le Havre) into Jurassic and Cretaceous asteroids (Breton, 1979, 1992).

Description. The holotype displays the abactinal surface, and includes the disc and portions of three arms. The arms are not strongly demarcated from the disc, and the interradius is rounded. The interradial superomarginals are evenly broad, and the external face is gently curved. The superomarginals at the base of the arm are slightly broader than in the interradius, and posses a broad abactinal surface. The single row of abactinals (radials) which separate the superomarginals of arm are nearly as broad as the superomarginals, and approximately square in outline. The paratype (Breton, 1992, pl. 38, fig. 1) displays the disc and the base of two arms. The superomarginals of the proximal arm are scarcely broader than those of the disc, and the radials separating the superomarginals of the arm are equally broad.

Remarks. Comptonia bretoni sp. nov. differs from C. elegans in the taller, broader interradial superomarginals which are less well demarcated from those of the arm. The adradials do not extend into the basal arm in C. bretoni sp. nov. but do so in C. elegans (Fig. 2F). 


\section{Conclusions}

The small asteroid fauna known from the Lower Greensand of southern England is described and revised taxonomically. It includes two taxa, both belonging to the Paxillosida, the pseudarchasterid Paragonaster wightensis (known from two partial, articulated individuals) and the astropectinid Coulonia caseyi sp. nov., represented only by isolated marginals. This is the first fossil record of the extant genus Paragonaster, and the oldest record of the Pseudarchasteridae. The genus Comptonia, known from the Albian of southern England and northern France, is closely related to Paragonaster. Two species are recognised, C. elegans and C. bretoni sp. nov.

\section{Acknowledgements}

I wish to thank Martin Simpson for providing access to the new specimen of $P$. wightensis, and Dr Tim Ewin for access to the NHM UK (London) collections. The manuscript was improved by John Jagt (referee) to whom I am most grateful.

\section{References}

Andrew, C., Gale, A.S., Howe, P., Paul, C.R.C., 2016. A new species of goniasterid starfish from the Upper Greensand Formation (Lower Cretaceous, Albian) of Lyme Regis, Dorset, UK. Geoscience in southwest England 13, 371-376.

Blake, D.B., 1973. Ossicle morphology of some Recent asteroids and description of some west American fossil asteroids. University of California Publications in Geological Sciences $104,1-59,19$ pls.

Blake, D.B., 1986. Some new post-Paleozoic sea stars (Asteroidea: Echinodermata) and comments on taxon endurance. Journal of Paleontology 60, 1103-1119.

Blake, D.B., Jagt, J.W.M., 2005. New latest Cretaceous and earliest Palaeogene asteroids (Echinodermata) from the Netherlands and Denmark and their palaeobiological significance. Bulletin de l'Institut royal des Sciences naturelles de Belgique, Sciences de la Terre $75,183-200$.

Blake, D.B., Reid, R., 1998. Some Albian (Cretaceous) asteroids (Echinodermata) from Texas and their paleobiological implications. Journal of Paleontology 72, 512-532. 
Breton, G., 1979. Les astéries du Crétacé de Normandie. Bulletin trimestriel de la Société géologique de Normandie et Amis du Muséum du Havre 65, 5-87.

Breton, G., 1992. Les Goniasteridae (Asteroidea, Echinodermata) jurassiques et crétacés de France: taphonomie, systématique, biostratigraphie, paléobiologie, évolution. Bulletin trimestriel de la Société géologique de Normandie et Amis du Muséum du Havre, Supplement to vol. 78, $590 \mathrm{pp}$.

Clarke, A.M., Downey, M.E., 1992. Starfishes of the Atlantic. Chapman \& Hall, London, 794 pp. Eagle, M.K., 1999. A new Early Miocene Pseudarchaster (Asteroidea: Echinodermata) from New Zealand. New Zealand Journal of Geology and Geophysics 42, 551-556.

Fisher, W.K., 1910. New starfishes from the North Pacific. 1. Phanerozonia.2. Spinulosida. Zoologischer Anzeiger 35, 545-553, 568-574.

Fisher, W.K., 1913. Four new genera and fifty-eight new species of starfishes from the Philippine Islands, Celebes and the Moluccas. Proceedings of the United States National Museum 43 (1944), 599-648.

Fisher, W.K., 1919. Starfishes of the Phillippine seas and adjacent waters.

Bulletin of the United States National Museum 3 (100), 1-547, pls 1-156.

Forbes, E., 1848. On the Asteridae found fossil in British Strata. Memoirs of the Geological Survey of Great Britain, British Organic Remains, Decade 2, 457-482.

Forbes, E., 1850. Echinodermata. In: Dixon, F. , The geology and fossils of the Tertiary and Cretaceous formations of Sussex, 422 pp., 50 pls. Longman, Brown, Green and Longmans, London.

Gale, A.S., 1987. Goniasteridae (Asteroidea, Echinodermata) from the Late Cretaceous of north-west Europe. 1. Introduction. The genera Metopaster and Recurvaster. Mesozoic Research 1, 1-69.

Gale, A.S., 1988. Goniasteridae (Asteroidea, Echinodermata) from the Late Cretaceous of north-west Europe. 2. The genera Calliderma, Crateraster, Nymphaster and Chomataster. Mesozoic Research 1, 151-186.

Gale, A.S., 2011a. Phylogeny of the Neoasteroidea (post-Palaeozoic Asteroidea, Echinodermata). Special Papers in Palaeontology 85, 1-112.

Gale, A.S., 2011b. The upper Oxfordian (Jurassic) asteroid fauna of Savigna, Jura, France. Swiss Journal of Palaeontology 130, 69-89.

Gale, A.S., 2018. Origin and phylogeny of velatid asteroids (Echinodermata, Neoasteroidea) new evidence from the Jurassic. Swiss Journal of Palaeontology, https://doi.org/10.1007/s13358-018-0155-z.123456789().,-- 
Goldring, R., Stephenson, D.G., 1972. The depositional environment of three starfish beds. Neues Jahrbuch für Geologie und Paläontologie, Monatshefte 1972(10), 611-624.

Gray, J.E.,1840. A synopsis of the genera and species of the Class Hypostoma (Asterias Linn.). Annals and Magazine of Natural History (1)6, 175-184, 275-290.

Halpern, J.A., 1972. Pseudarchasterinae (Echinodermata, Asteroidea) of the Atlantic. Proceedings of the Biological Society of Washington 85, 359-384.

Hess, H., 1955. Die fossilen Astropectinidae (Asteroidea). Schweitzerische Paläontologische Abhandlungen 71, 1-113, 4 pls.

Hess, H., Blake, D.B., 1995. Coulonia platyspina n. sp., a new astropectinid sea star from the Lower Cretaceous of Morocco. Eclogae Geologicae Helvetiae 88, 777-788.

Loriol, P. de, 1873. Description de quelques Astérides du terrain néocomien des environs de Neuchâtel. Mémoires de la Société Scientifique naturelle de Neuchâtel 4(2), 1-30.

Mah, C., Foltz, D., 2011. Molecular phylogeny of the Valvatacea. Zoological Journal of the Linnean Society 161, 769-788.

Müller, A.H., 1953. Die isolierten Skelettelemente der Asteroidea (Asterozoa) aus der Obersenonen Schreibkreide von Rügen. Beihefte zum Geologischen Jahrbuch 8, 1-66, 11 pls.

Perrier, E., 1884. Mémoire sur les étoiles de mer recueillis dans la Mer des Antilles et la Golfe de Mexique. Nouvelles Archives du Muséum d'Histoire naturelle de Paris 6(2), 127276.

Sladen, W.P., 1889. Report on the Asteroidea. Report on the Scientific Results of the Voyage of H.M.S. Challenger during the years 1873-1876, Zoology 30(51), xlii + 893 pp., 118 pls.

Spencer, W.K., 1905. A monograph on the British fossil Echinodermata from the Cretaceous formations. Palaeontographical Society London (Monograph), Volume 2. The Asteroidea and Ophiuroidea. Part 3, 67-90, pls 17-26.

Spencer, W.K., 1907. A monograph on the British fossil Echinodermata from the Cretaceous formations. Palaeontographical Society London (Monograph), Volume 2. The Asteroidea and Ophiuroidea. Part 4, 91-132, pls 27-29..

Spencer, W.K., 1913. The evolution of the Cretaceous Asteroidea. Philosophical Transactions of the Royal Society London B204, 99-177.

Spencer, W.K., Wright, C.W., 1966. Asterozoans, pp. U4-U107. In Moore, R.C. (Editor), Treatise on Invertebrate Paleontology, Echinodermata, 3 (1). Geological Society of America, Boulder, Colorado and The University of Kansas Press, Lawrence, Kansas, 366 pp. 


\section{Captions}

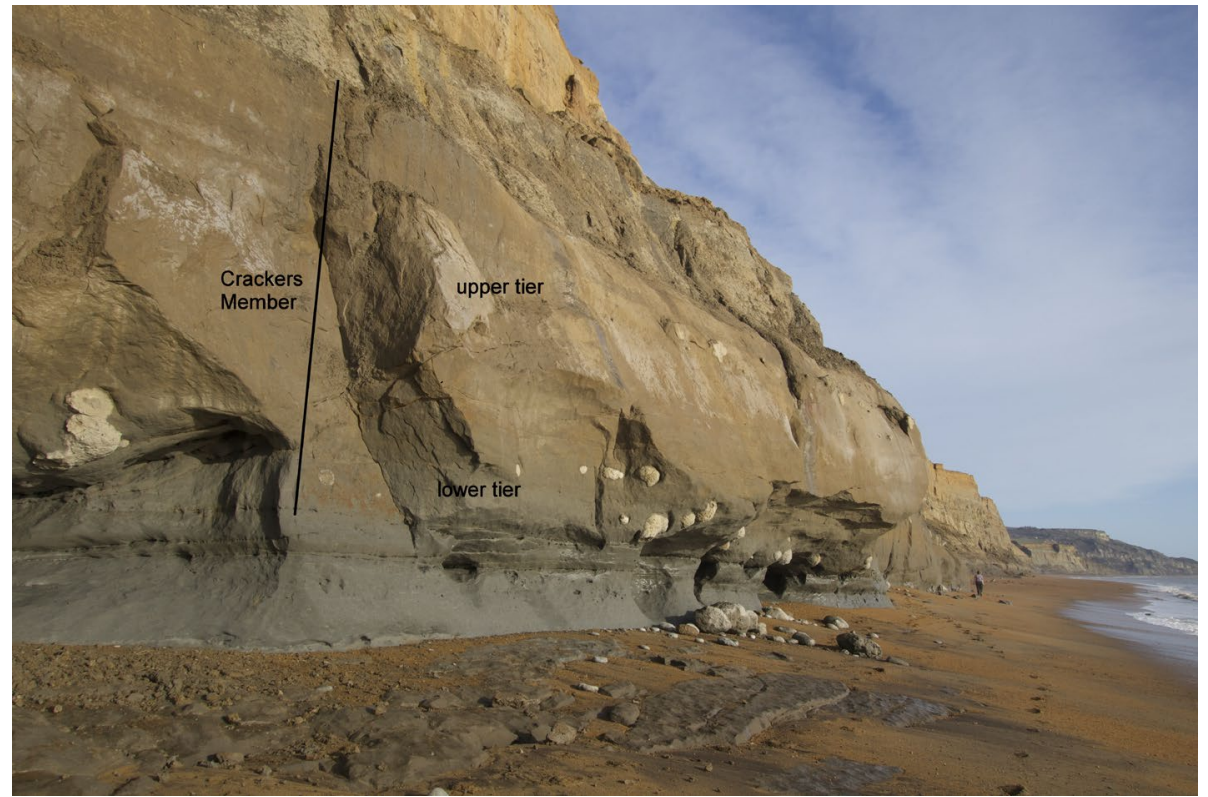

Fig. 1.

Chale Bay, looking eastwards to the Crackers - large pale concretions set in fine silty sand. The soft cores of these occasionally contain well-preserved fossils, including very rare asteroids. The Crackers Member is marked, with discrete upper and lower tiers of concretions.

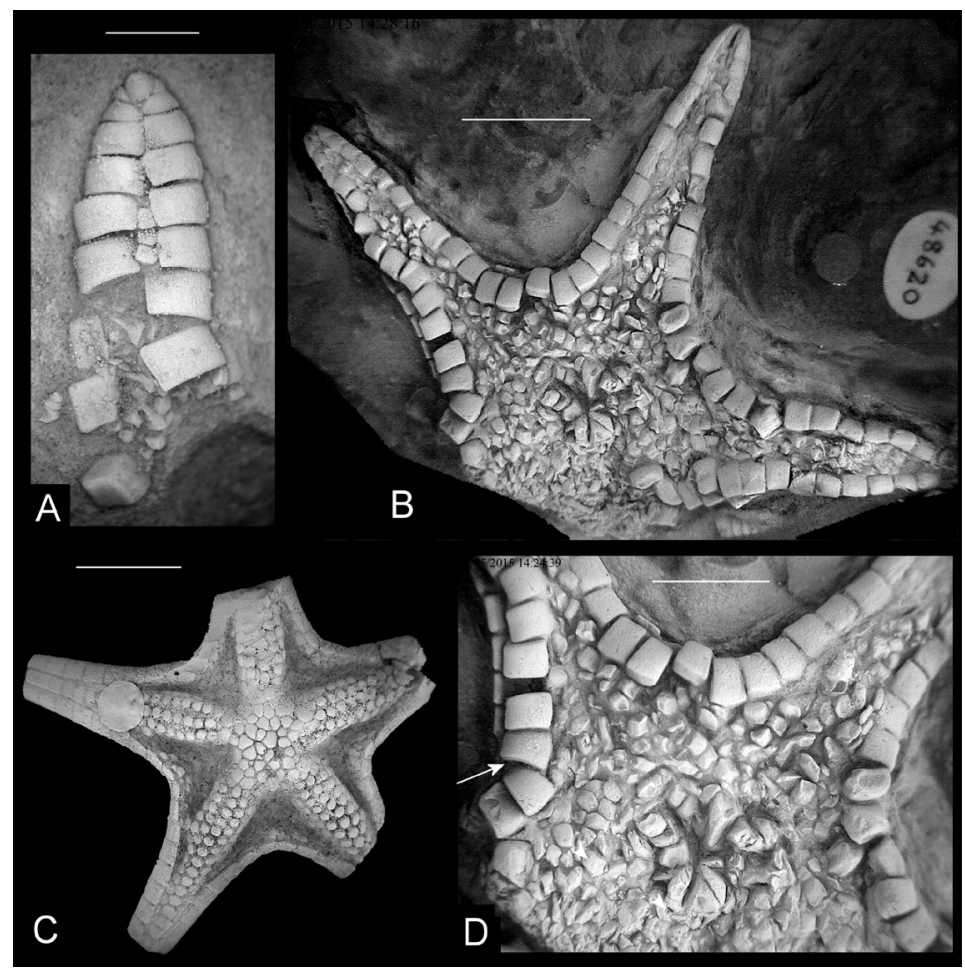




\section{Fig. 2}

A-B, D, Paragonaster wightensis (Breton, 1992). A, arm tip showing abactinal surface. Note small radial ossicles set between superomarginals, and the unpaired terminal ossicle. IWCMS 2019.3. B, D, actinal surface of incomplete individual, the original of Spencer (1905, pl. 19, fig. 3) and Breton (1992, pl. 38, fig. 4). B, entire specimen; D, enlargement of disc. Note (arrowed) slightly depressed short intermarginal groove to accommodate shallow intermarginal fasciole. NHMUK 48620 (ex Saxby Collection); both from the Crackers Member, Atherfield Clay, Chale Bay (Isle of Wight, UK); lower Aptian, Deshayesites deshayesi Zone. C, Comptonia elegans Gray, 1840. Lectotype, the original of Forbes, in Dixon (1850, pl. 22, fig. 9), Spencer (1905, pl. 17, fig. 4) and Gale, in Andrew et al. (2016, fig. 1C). Abactinal view; note radial plates extending into arm between superomarginals. Hysteroceras varicosum Subzone, Blackdown, Devon, UK (NHMUK E2567). Scale bars equal $5 \mathrm{~mm}(\mathrm{~A}, \mathrm{D})$ and $10 \mathrm{~mm}(\mathrm{~B}, \mathrm{C})$.

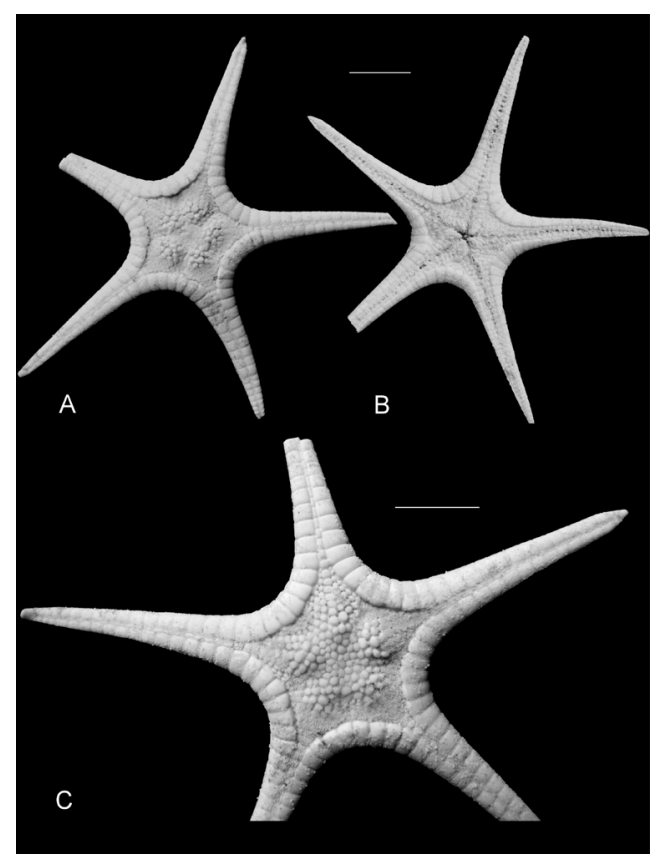

Fig. 3

Paragonaster stenostichus Fisher, 1913. Abactinal (A) and actinal (B) views of an individual retaining all its granular spines. $\mathrm{C}$, enlarged abactinal aspect of disc and proximal arm, partly denuded of spines, to show abactinals of the disc and the single row of abactinal plates (radials) set between the superomarginals and extending nearly to the tip of the arm. Philippines, purchased ASG. Scale bar equals $10 \mathrm{~mm}$. 


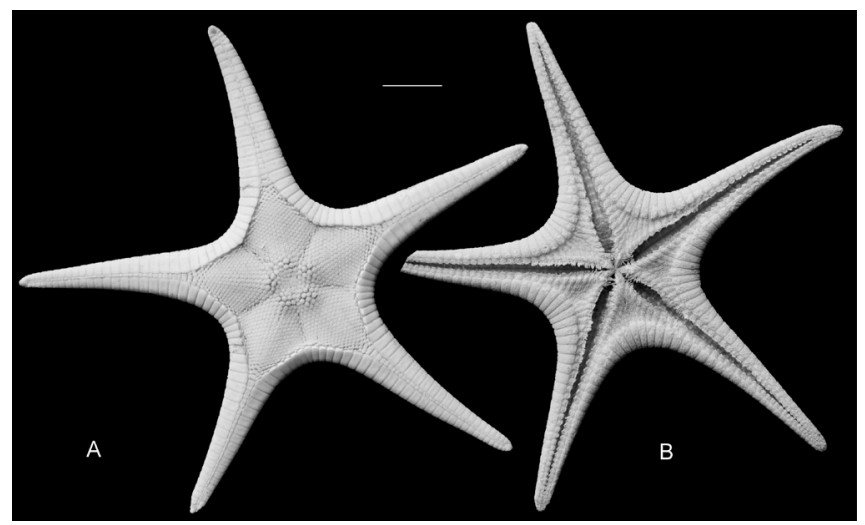

Fig. 4.

Perissogonaster insignis Fisher, 1913. Abactinal (A) and actinal (B) views of a small individual. Note the single row of abactinal plates (radials) set between the superomarginals and extending nearly to the tip of the arm. Philippines, purchased ASG. Scale bar equals $10 \mathrm{~mm}$.

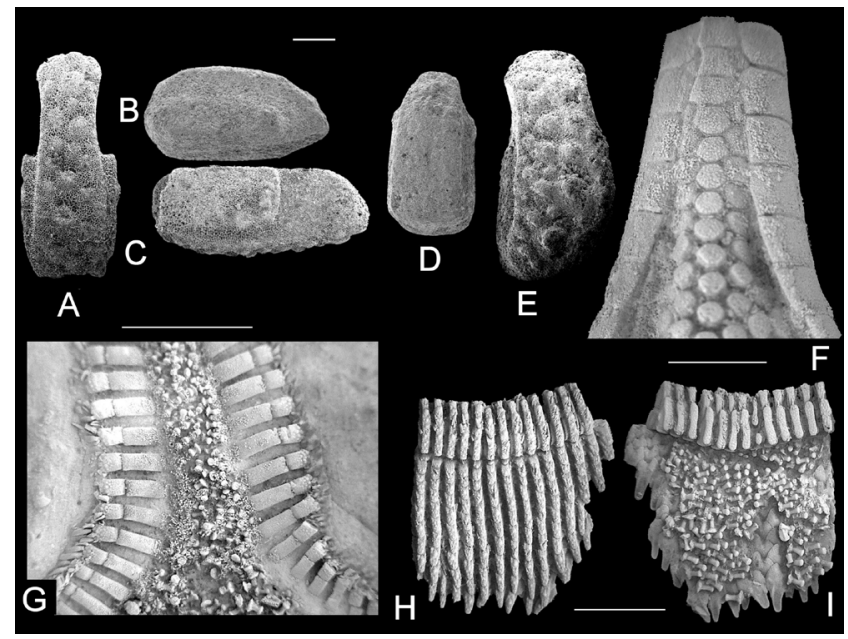

Fig. 5

A-E, Coulonia caseyi sp. nov. A, C, E, inferomarginals. A, C, well-preserved median inferomarginal, in actinal (A) and proximal (C) views. Holotype, NHMUK EE 16662. E, actinal view of an inferomarginal from the base of the arm. NHMUK EE 16664. B, D, median superomarginal, in proximal (B) and abactinal (D) aspect. NHMUK EE 16663. All from the Crackers Member, Atherfield Clay, Atherfield (Isle of Wight, UK), collected C.W. and E.V. Wright, 1947. F, Comptonia elegans Gray, 1840. Lectotype, the original of Forbes, in Dixon (1850, pl. 22, fig. 9), Spencer (1905, pl. 17, fig. 4) and Gale, in Andrew et al. (2016, fig. 1C). Abactinal view, showing radial and adradial plates extending into the arm between the superomarginals. Hysteroceras varicosum Subzone, Blackdown, Devon, UK (NHMUK E 2567). G, Coulonia platyspina Hess and Blake, 1995. Base of arm, to show lateral extension of inferomarginals beyond the lateral border of the superomarginals, and flattened, short 
infermarginal spines. Barremian, Toda, Agadir Basin, Morocco. NHMUK. H, I, Coulonia reidi (Blake and Reid, 1998), actinal (H) and abactinal (I) views of a portion of the disc, to show broad, short inferomarginals, relatively narrow superomarginals, and well-defined channels between imbricated actinal ossicles which housed fasciolar channels. Grayson Formation, lower Cenomanian, Dottie Lynn Lane, Fort Worth, Texas, USA. A. S. Gale coll. Scale bars equal $0.5 \mathrm{~mm}(\mathrm{~A}-\mathrm{E}), 5 \mathrm{~mm}(\mathrm{~F})$ and $10 \mathrm{~mm}(\mathrm{G}-\mathrm{I})$. 